\title{
Inadequate protein delivery on an intensive care unit
}

\author{
L. Hill, M. Snazelle, T. Salih, E. Kyriakidou, G. Mandersloot and J. Hadley \\ The Royal London Hospital, Barts and the London NHS Trust, Whitechapel, London, E1 1BB, UK
}

It is known that delivery of enteral nutrition in the Intensive Care Unit (ICU) is often suboptimal ${ }^{(1)}$. Our ICU provides care to a wide range of clinical areas including trauma. In a recent audit we identified that on average only $68 \%$ (range 0 to $117 \%$ ) of prescribed feed was delivered. Routinely our 'first-line' choice of enteral tube feed is a $1 \mathrm{kcal} / \mathrm{ml}$ feed containing $0.04 \mathrm{~g}$ protein per kcal. We wished to identify the adequacy of protein delivery against estimated requirements when using this feed.

We used previously collected audit data of 50 consecutive admissions to the ICU at the Royal London Hospital. Data collected included weight (estimated or actual), height/measured length, calculated BMI, estimated energy and protein requirements (calculated using accepted guidelines $\left.{ }^{(1)}\right)$, feed prescription and daily volume of feed delivered. The amount of protein from the prescribed volume of feed was compared to daily estimated protein requirements.

Of the 50 patients, 22 were excluded from analysis (15 were not enterally tube fed or not assessed by a dietitian due to a short admission, two had parenteral nutrition and five were prescribed an alternative enteral tube feed). The remaining 28 patients were prescribed a standard polymeric feed $(1 \mathrm{kcal} / \mathrm{ml}, 0.04 \mathrm{~g}$ protein $/ \mathrm{kcal})$ which met patients' estimated energy requirements. $27(96 \%)$ of these prescriptions did not meet estimated protein requirements and one $(4 \%)$ met estimated requirements.

Enteral tube feeds with higher protein content are available in the United Kingdom (two alternative formulations of available feeds are given below). We therefore calculated the required volume of feed that would be required for each patient in our audit using these alternative feeds. From this we predicted protein delivered if using the two alternative feed formulations (assuming $100 \%$ delivery).

\begin{tabular}{lc}
\hline & Number of patients $(\%)$ in which feed would meet estimated requirements for protein \\
\cline { 2 - 2 } Feed type & Does not meet requirements \\
\hline Current feed $1 \mathrm{kcal} / \mathrm{ml}, 0.04 \mathrm{~g}$ protein $/ \mathrm{kcal}$ & $27(96)$ \\
Alternative Feed $11.5 \mathrm{kcal} / \mathrm{ml}, 0.05 \mathrm{~g}$ protein $/ \mathrm{kcal}(0.075 \mathrm{~g} / \mathrm{ml})$ & $13(46)$ \\
Alternative Feed $21 \mathrm{kcal} / \mathrm{ml}, 0.062 \mathrm{~g} / \mathrm{kcal}$ & $5(18)$ \\
\hline
\end{tabular}

Both alternative higher protein content feeds improved the number of patients that would have a feed prescription meeting their estimated protein requirements. The alternative feed containing $1 \mathrm{kcal} / \mathrm{ml}$ and $0.062 \mathrm{~g}$ protein/kcal was most successful at meeting patients' estimated protein requirements ( $82 \%$ of patients).

Protein delivery using a standard $1 \mathrm{kcal} / \mathrm{ml}$ feed $(0.04 \mathrm{~g}$ protein $/ \mathrm{kcal})$ did not meet requirements for most patients. Protein delivery is further reduced when feed delivery is inadequate. An enteral tube feed with increased protein should be considered on our ICU. Strategies to improve enteral feed delivery are also required.

1. McClave SA, Sexton LK, Spain DA, Adams JL, Owens NA, Sullins, MB, Blandford BS, et al. (1999) Enteral tube feeding in the intensive care unit: factors impeding adequate delivery. Crit Care Med 27, 1252-6.

2. Kreymann KG, Berger MM, Deutz NE, Hiesmayr M, Jolliet P, Kazandjiev G, Nitenberg G, van den Berghe G, Wernerman J DGEM, Ebner C, Hartl W, Heymann C, Spies C; ESPEN (European Society for Parenteral and Enteral Nutrition) (2006) ESPEN Guidelines on Enteral Nutrition: Intensive care. Clin Nutr 25(2):210-23. 